\title{
Activated phenotype in neutrophils and monocytes from patients with primary proliferative polycythaemia
}

\author{
N B Westwood, E R Copson, L A Page, A R Mire-Sluis, K A Brown, T C Pearson
}

\begin{abstract}
Aim-To investigate whether monocytes and neutrophils from patients with primary proliferative polycythaemia (PPP) exhibit increased expression of markers of cell activation and, if so, whether they are associated with the phagocytic activity of these cells and concentrations of cir-
\end{abstract} culating cytokines.

Methods-Expression of CD11b, CD14, CD18, and CD64 on monocytes and neutrophils was assessed by flow cytometry. Phagocytosis was analysed using immunoglobulin opsonised Escherichia coli. Serum concentrations of granulocyte colony stimulating factor (G-CSF), granulocyte-macrophage CSF (GM-CSF) and macrophage CSF (M-CSF) were determined by bioassays, and interferon- $\gamma$ (IFN- $\gamma$ ) by enzyme linked immunosorbent assay (ELISA).

Results-Patients with PPP $(n=18)$, when compared with normal subjects $(n=10)$, had increased percentages of CD64+ monocytes (52\% v 36\%) and neutrophils $(42 \% v 11 \%)$ and of CD14 + neutrophils $(36 \% v 18 \%)$. Monocytes from patients with PPP exhibited increased expression of CD64 (47 $v$ 26) and of CD11b (65 $v$ 36). These abnormalities were not found in patients with secondary $(n=8)$ or apparent $(n=13)$ polycythaemia. The percentage of neutrophils undergoing phagocytosis was higher in patients with PPP (mean 64\%; $n=6$ ) than in normal subjects (mean $42 \%$; $n=5)$. G-CSF, GM-CSF and IFN- $\gamma$ concentrations in patients' serum samples were comparable with normal; M-CSF was not detected in any of the samples. There was no correlation between cytokine concentrations and the expression of CD11b, CD14, CD18, and CD64 on patients' phagocytes.

Conclusions-Increased expression of CD11b and CD64 by monocytes, increased percentages of $\mathrm{CD14}+$ and CD64 + neutrophils and the high phagocytic activity of neutrophils suggests that these cells are activated in vivo in patients with PPP. The phenotypic changes of PPP phagocytes were not associated with increased concentrations of circulating cytokines and probably reflect intrinsic abnormalities within the neoplastic PPP clone.

( $f$ Clin Pathol 1995;48:525-530)

Keywords: CD antigen, primary polycythaemia, neutrophil activation, monocyte activation.
Primary proliferative polycythaemia (PPP, polycythaemia vera) is a clonal myeloproliferative disorder originating in a neoplastic multilineage stem cell. ${ }^{1}$ The principal clinical features of PPP are related to the increased red cell mass and abnormal platelet function. ${ }^{2}$ Granulocytosis is also a frequent finding in PPP and, in most patients, all circulating neutrophils appear to be derived from the abnormal stem cell. ${ }^{3}$ Monocytes are also likely to be part of the abnormal clone as they and neutrophils are derived from a common antecedent, the colony forming unit granulocyte-macrophage. ${ }^{4}$

Previous studies demonstrate that unstimulated PPP neutrophils have a high glycogen content ${ }^{5}$ and exhibit increased alkaline phosphatase activity, ${ }^{6}$ glycogenolysis, ${ }^{7}$ glucose oxidisation, oxygen consumption, and nitroblue tetrazolium reduction, ${ }^{8}$ suggesting that these cells are metabolically activated in vivo. However, there are conflicting reports concerning neutrophil migration, ${ }^{9-11}$ adherence ${ }^{1213}$ and phagocytic activity ${ }^{14}$ in PPP and the question of whether neutrophils are functionally activated in PPP remains controversial. Moreover, there have been no equivalent studies of monocytes in these patients.

Many of the functions of monocytes and neutrophils are mediated by surface receptors, the expression of which is upregulated upon activation. For example, the expression of CD11b/CD18 (Mac-1, CR3), which promotes adherence to endothelium and phagocytosis of iC3b coated particles, increases rapidly following phagocyte activation. ${ }^{15} \mathrm{CD} 14$, a receptor for lipopolysaccharide (LPS)-LPS binding protein complexes, expressed strongly by monocytes but weakly by neutrophils, ${ }^{16}$ is upregulated on neutrophils stimulated with cytokines and chemoattractants. ${ }^{17}$ Similarly, CD64, the high affinity receptor for IgG $(\mathrm{Fc} \gamma \mathrm{RI})$, is strongly upregulated on monocytes $^{18}$ and neutrophils ${ }^{19}$ by interferon- $\gamma$ (IFN$\gamma)$. Consequently, CD64 is considered to be a marker of neutrophil activation: it promotes the recognition ${ }^{20}$ and phagocytosis ${ }^{21}$ of IgG coated erythrocytes and activates the oxidative responses of neutrophils. ${ }^{19}$

In the present study we have therefore determined the expression of CD11b/CD18, CD14 and CD64 on monocytes and neutrophils from patients with PPP and have assessed the phagocytic activity of these cells in order to elicit evidence of in vivo activation. Blood concentrations of colony stimulating factors (CSFs) and IFN- $\gamma$ were also measured to determine whether changes in surface pheno- 
type or phagocytic activity, or both, were associated with increased concentrations of endogenous phagocyte activating cytokines.

\section{Methods}

The study population comprised 21 patients fulfilling the criteria for PPP; ${ }^{22}$ eight patients with secondary polycythaemia, caused by hypoxaemic chronic obstructive airways disease in five and by cyanotic congenital heart disease in the other three; 13 patients with a raised haematocrit but normal red cell mass (apparent polycythaemia); and 15 normal subjects. Patients were managed by venesection and in those with PPP busulphan was given intermittently to control elevated platelet counts. Of the PPP group, 12 had a granulocytosis (range 8.1-16.1 $\times 10^{9} / 1$ ) and one had a monocytosis $\left(1 \cdot 1 \times 10^{9} / 1\right)$ at the time of the study. Leucocyte counts of all other subjects were normal.

\section{SURFACE RECEPTOR ANALYSIS}

Monoclonal antibodies to CD11b (Becton Dickinson, Oxford, UK), CD14, CD18, (Dako, High Wycombe, UK), and CD64 (Serotec, Oxford, UK) were used for immunofluorescence staining of whole blood followed by flow cytometry (Coulter, Luton, UK). Monocytes and neutrophils were identified by forward and side scatter characteristics and the percentage of labelled cells determined from 1024 channel fluorescence histograms set to $\leq 2 \%$ using isotype controls. The relative level of receptor expression was estimated using the mean fluorescence channel (MFC) of stained cells. Sterile endotoxin-free reagents and aseptic technique were used throughout to minimise the possibility of in vitro cell activation, and the optical alignment and fluorescence sensitivity of the instrument were checked daily.

\section{PHAGOCYTOSIS ASSAY}

Immunoglobulin opsonised fluorescein isothiocyanate (FITC) labelled Escherichia coli (Orpegen, Heidelberg, Germany) were incubated with whole blood $\left(2.5 \times 10^{7} \mathrm{E}\right.$ coli $/ \mathrm{ml}$ blood) at $37^{\circ} \mathrm{C}$. Aliquots were removed at intervals up to 90 minutes and mixed with ice cold trypan blue solution to halt phagocytosis and quench fluorescence from adherent $E$ coli. Monocytes and neutrophils were identified by flow cytometry as described above, in conjunction with propidium iodide staining to eliminate uningested bacteria and leucocyte aggregates from the analysis. The percentage of cells undergoing phagocytosis was then determined from histograms of FITC fluorescence. Plots of per cent phagocytosis against time, fitted using commercial software (Fig.P Biosoft, Cambridge, UK), approximated asymmetric sigmoidal curves with maxima between 20 and 60 minutes. These curves were used to interpolate the time taken to reach halfmaximum values of phagocytosis as an estimate of the rate of phagocytosis.

\section{CYTOKINE ASSAYS}

Granulocyte CSF (G-CSF), granulocytemacrophage CSF (GM-CSF) and macrophage CSF (M-CSF) were measured using cell proliferation bioassays. ${ }^{23}$ Briefly, serum samples were incubated with GNFS60 (G-CSF assay), TF1 (GM-CSF) or MNFS60 (M-CSF) factor dependent cells at $37^{\circ} \mathrm{C}$ in $5 \% \mathrm{CO}_{2}$ for 48 hours. Cultures were then pulsed with ${ }^{3} \mathrm{H}$ thymidine (Amersham, Little Chalfont, UK), harvested onto filters and read in a scintillation counter. Assays were calibrated using the World Health Organisation International Standards (National Institute for Biological Standards and Control, NIBSC*): G-CSF (NIBSC reference 88/502); GM-CSF (88/646); M-CSF (90/ 732). Serum samples stimulating TF1 cells were retested in the presence of a neutralising antibody to erythropoietin and the identity of any residual activity confirmed using anti-GMCSF. Serum IFN- $\gamma$ was measured by enzyme linked immunosorbent assay (ELISA) ${ }^{24}$ using microtitre plates (Falcon, Becton Dickinson) coated with murine monoclonal antihuman IFN- $\gamma$ (NIBSC). Non-specific binding was blocked using $1 \%$ human albumin, followed by sequential incubations with serum samples, rabbit polyclonal antihuman IFN- $\gamma$ (NIBSC), peroxidase conjugated goat antirabbit immunoglobulin (Biorad, Hemel Hempstead, UK) and substrate (tetra-methylbenzidine/ hydrogen peroxide). Colour development was stopped with sulphuric acid (2M) and absorbance read at $450 \mathrm{~nm}$. The British Standard preparation of IFN- $\gamma$ (NIBSC 82/587) was used for the calibration curve.

\section{STATISTICS}

Intergroup comparisons were made using the Student's $t$ test, Wilcoxon's rank sum or the $\chi^{2}$ test; $p<0.05$ was considered significant.

\section{Results}

\section{SURFACE RECEPTOR ANALYSIS}

The percentage of CD64 + monocytes was higher in patients with PPP (mean $52 \%$ ) than in normal subjects (mean $36 \%$; $<<0.05$; fig 1A) and the expression of CD64 on PPP monocytes was increased (mean MFC in PPP, 47; normal mean MFC, 26; p $<0.0001$; fig 1B). The percentage of neutrophils expressing CD64 was also higher in patients with PPP (mean $42 \%$ ) than in normal subjects (mean $11 \% ; \mathrm{p}<0.0001$; fig 2A), although the level of CD64 expression on these cells was not increased (fig 2A). Table 1 shows that patients with PPP also had increased expression of CD11b on monocytes (PPP mean MFC, 65; normal mean MFC, 36; $\mathrm{p}<0.05)$ and a high percentage of CD14+ neutrophils (PPP mean, 36\%; normal mean, $18 \%$; $<0.001)$. When monocyte CD11b (MFC), monocyte CD64 (\% and MFC), neutrophil CD14 (\%), and neutrophil CD64 (\%) were assessed in each patient with PPP the

* The National Institute for Biological Standards and Control, P.O. Box 1193, Potters Bar, Hertfordshire EN6 3QG. 


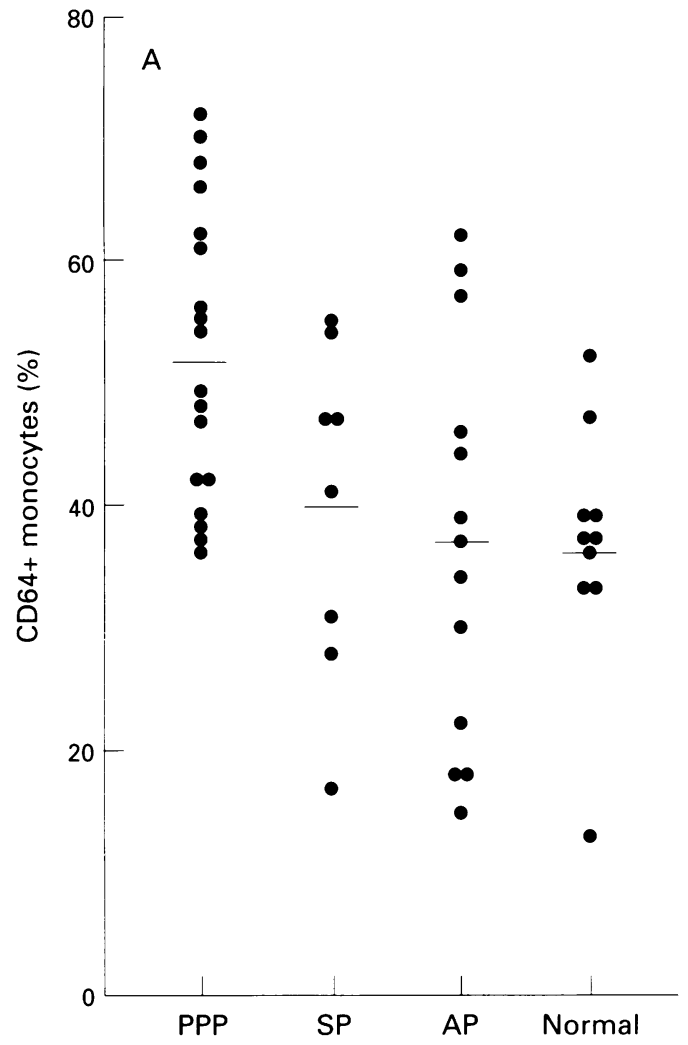

presentation but has not required venesection for over 20 years and therefore is atypical.

In contrast to those with PPP, monocytes and neutrophils from patients with secondary polycythaemia and apparent polycythaemia were
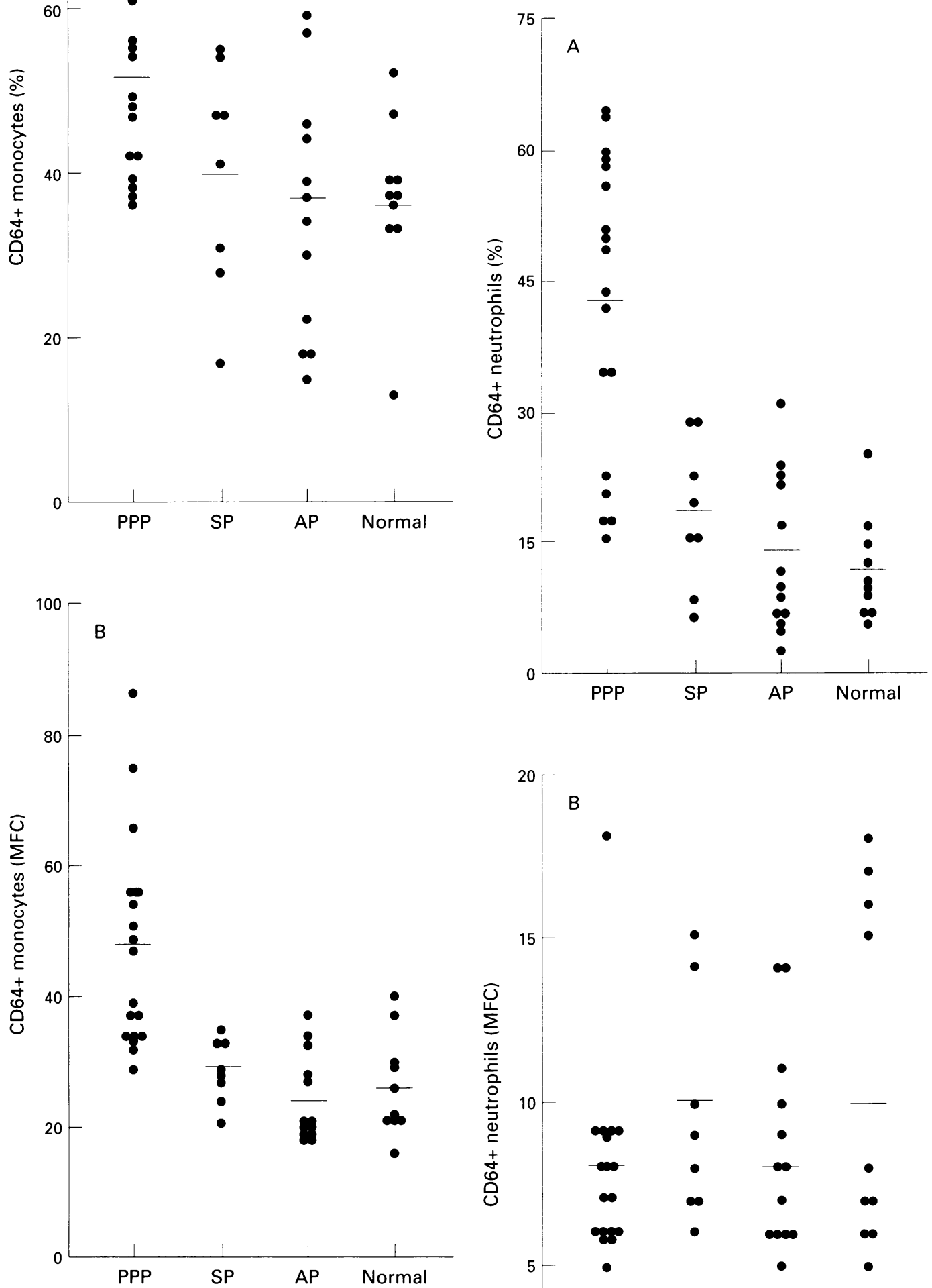

Figure 1 The percentage of CD64+ monocytes (panel $A)$ and relative level of CD64 expression (panel B) on monocytes from patients with polycythaemia and normal subjects. Horizontal lines indicate mean values. SP,

secondary polycythaemia; AP, apparent polycythaemia.

majority $(17 / 18)$ were found to have two or more results that were greater than the maximum values observed in normal subjects. The single patient who was entirely comparable with normal subjects met the criteria for $\mathrm{PPP}^{22}$ at

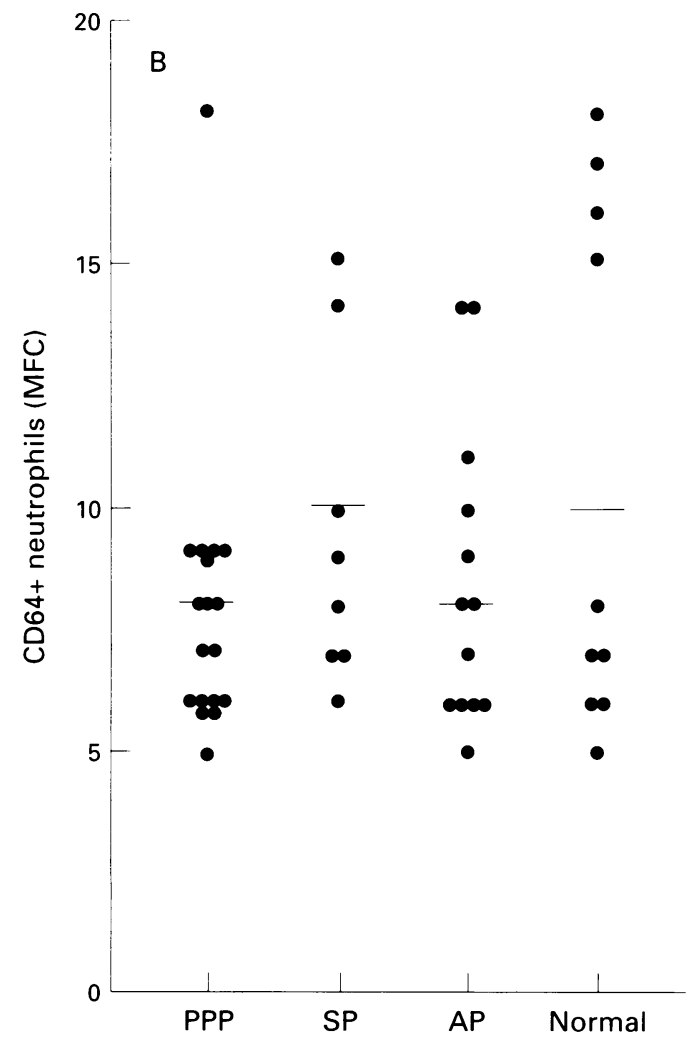

Figure 2 The percentage of CD64+ neutrophils (panel $A)$ and relative level of $C D 64$ expression (panel B) on neutrophils from patients with polycythaemia and normal subjects. Horizontal lines indicate mean values. SP, secondary polycythaemia; AP, apparent polycythaemia. 
Table 1 Expression of CD11b/CD18,CD14 and CD64 on monocytes and neutrophils from patients with polycythaemia

\begin{tabular}{|c|c|c|c|c|c|c|c|c|}
\hline \multirow[b]{2}{*}{ Surface receptor } & \multicolumn{4}{|c|}{ Monocytes } & \multicolumn{4}{|c|}{ Neutrophils } \\
\hline & $\begin{array}{l}P P P \\
(n=18)\end{array}$ & $\begin{array}{l}S P \\
(n=8)\end{array}$ & $\begin{array}{l}A P \\
(n=13)\end{array}$ & $\begin{array}{l}\text { Normal } \\
(n=10)\end{array}$ & $\begin{array}{l}P P P \\
(n=18)\end{array}$ & $\begin{array}{l}S P \\
(n=8)\end{array}$ & $\begin{array}{l}A P \\
(n=13)\end{array}$ & $\begin{array}{l}\text { Normal } \\
(n=10)\end{array}$ \\
\hline \multicolumn{9}{|l|}{ CD11b } \\
\hline$\%$ & $\begin{array}{l}99 \\
(0 \cdot 3)\end{array}$ & $\begin{array}{l}99 \\
(0 \cdot 2)\end{array}$ & $\begin{array}{l}99 \\
(0 \cdot 3)\end{array}$ & $\begin{array}{l}99 \\
(0 \cdot 3)\end{array}$ & $\begin{array}{l}100 \\
(0 \cdot 1)\end{array}$ & $\begin{array}{l}100 \\
(0 \cdot 2)\end{array}$ & $\begin{array}{l}100 \\
(0 \cdot 2)\end{array}$ & $\begin{array}{l}100 \\
(0 \cdot 2)\end{array}$ \\
\hline MFC & $\begin{array}{l}65^{*} \\
(9)\end{array}$ & $\begin{array}{l}54 \\
(9)\end{array}$ & $\begin{array}{l}51 \\
(9)\end{array}$ & $\begin{array}{l}36 \\
(6)\end{array}$ & $\begin{array}{l}42 \\
(6)\end{array}$ & $\begin{array}{l}39 \\
(8)\end{array}$ & $\begin{array}{l}46 \\
(9)\end{array}$ & $\begin{array}{l}39 \\
(13)\end{array}$ \\
\hline \multicolumn{9}{|l|}{$\mathrm{CD} 14$} \\
\hline$\%$ & $\begin{array}{l}75 \\
(2)\end{array}$ & $\begin{array}{l}75 \\
(2)\end{array}$ & $\begin{array}{l}80 \\
(2)\end{array}$ & $\begin{array}{l}78 \\
(3)\end{array}$ & $\begin{array}{l}36^{* * *} \\
(3)\end{array}$ & $\begin{array}{c}14 \\
(2)\end{array}$ & $\begin{array}{c}24 \\
(2)\end{array}$ & $\begin{array}{c}18 \\
(3)\end{array}$ \\
\hline MFC & $\begin{array}{l}91 \\
(6)\end{array}$ & $\begin{array}{l}68^{*} \\
(5)\end{array}$ & $\begin{array}{l}92 \\
(9)\end{array}$ & $\begin{array}{l}91 \\
(5)\end{array}$ & $(1)^{8}$ & $\begin{array}{l}13 \\
(2)\end{array}$ & $\begin{array}{c}8 \\
(0 \cdot 4)\end{array}$ & $\begin{array}{l}10 \\
(2)\end{array}$ \\
\hline \multicolumn{9}{|l|}{ CD18 } \\
\hline$\%$ & $\begin{array}{l}82 \\
(3)\end{array}$ & $\begin{array}{l}72 \\
(4)\end{array}$ & $\begin{array}{l}86 \\
(3)\end{array}$ & $\begin{array}{l}80 \\
(4)\end{array}$ & $\begin{array}{l}94 \\
(2)\end{array}$ & $\begin{array}{c}83 \\
(4)\end{array}$ & $\begin{array}{c}94 \\
(2)\end{array}$ & $\begin{array}{l}93 \\
(2)\end{array}$ \\
\hline MFC & $\begin{array}{l}77 \\
(5)\end{array}$ & $\begin{array}{l}73 \\
(5)\end{array}$ & $\begin{array}{l}69 \\
(5)\end{array}$ & $\begin{array}{l}66 \\
(3)\end{array}$ & $\begin{array}{l}35 \\
(4)\end{array}$ & $\begin{array}{l}39 \\
(7)\end{array}$ & $\begin{array}{l}36 \\
(3)\end{array}$ & $\begin{array}{l}37 \\
(4)\end{array}$ \\
\hline \multicolumn{9}{|l|}{ CD64 } \\
\hline$\%$ & $\begin{array}{l}52 * \\
(3)\end{array}$ & $\begin{array}{l}40 \\
(5)\end{array}$ & $\begin{array}{l}37 \\
(5)\end{array}$ & $\begin{array}{l}36 \\
(3)\end{array}$ & $\begin{array}{l}42 \dagger \\
(4)\end{array}$ & $\begin{array}{c}18 \\
(3)\end{array}$ & $\begin{array}{c}13 \\
(3)\end{array}$ & $\begin{array}{l}11 \\
(2)\end{array}$ \\
\hline MFC & $\begin{array}{l}47 \dagger \\
(4)\end{array}$ & $\begin{array}{l}29 \\
(2)\end{array}$ & $\begin{array}{l}24 \\
(2)\end{array}$ & $\begin{array}{l}26 \\
(2)\end{array}$ & ${ }^{8}$ & $\begin{array}{l}10 \\
(1)\end{array}$ & ${ }^{8}{ }^{8}$ & $\begin{array}{l}10 \\
(2)\end{array}$ \\
\hline
\end{tabular}

Values are expressed as mean (SEM).

Mean values significantly different from normal (Student's $t$ test): ${ }^{*} \mathrm{p}<0.05,{ }^{* * *} \mathrm{p}<0.001,+\mathrm{p}<0.0001$.

SP, secondary polycythaemia; AP, apparent polycythaemia.

comparable with normal, except for lower expression of CD14 on secondary polycythaemia monocytes (MFC in secondary polycythaemia, 68; normal MFC, $91 ; \mathrm{p}<0.01$; table 1$)$.

\section{PHAGOCYTOSIS}

As shown in table 2 , the percentage of neutrophils undergoing phagocytosis was higher in patients with PPP (mean 64\%) than in normal subjects (mean $42 \% ; \mathrm{p}<0.02$ ). The time taken to reach half-maximum phagocytosis was lower, but not significantly, in those with PPP

Table 2 Phagocytic activity of neutrophils and monocytes from patients with polycythaemia

\begin{tabular}{llll}
\hline & $\begin{array}{l}P P P \\
(n=6)\end{array}$ & $\begin{array}{l}A P \\
(n=5)\end{array}$ & $\begin{array}{l}\text { Normal } \\
(n=5)\end{array}$ \\
\hline $\begin{array}{l}\text { Neutrophils } \\
\text { undergoing } \\
\text { phagocytosis (\%) }\end{array}$ & $\begin{array}{l}64^{*} \\
(4)\end{array}$ & $\begin{array}{l} \\
(5)\end{array}$ & $\begin{array}{l}42 \\
(5)\end{array}$ \\
$\begin{array}{l}\text { Monocytes undergoing } \\
\text { phagocytosis (\%) }\end{array}$ & 31 & 18 & 24 \\
& $(6)$ & $(4)$ & $(2)$ \\
\hline
\end{tabular}

Values are expressed as mean (SEM) of the maximum percentage of cells undergoing phagocytosis during a 90 minute incubation with immunoglobulin opsonised $E$ coli. ${ }^{*} \mathrm{p}<0 \cdot 02$ compared with normal group mean (Wilcoxon's rank sum test) $\mathrm{AP}$, apparent polycythaemia.

Table 3 Cytokine concentrations in the serum samples of patients with polycythaemia

\begin{tabular}{|c|c|c|c|c|}
\hline Cytokine & $\begin{array}{l}P P P \\
(n=14)\end{array}$ & $\begin{array}{l}S P \\
(n=7)\end{array}$ & $\begin{array}{l}A P \\
(n=12)\end{array}$ & $\begin{array}{l}\text { Normal } \\
(n=10)\end{array}$ \\
\hline $\begin{array}{l}\text { G-CSF }(\mathrm{pg} / \mathrm{ml}) \\
\text { No. of positive samples } \\
\text { mean }(\mathrm{SEM})^{\mathrm{b}} \\
\text { range }\end{array}$ & $\begin{array}{l}11 \\
25 \cdot 1(3 \cdot 0) \\
8 \cdot 7-49 \cdot 8\end{array}$ & $\begin{array}{c}4 \\
22 \cdot 5(5 \cdot 8) \\
11 \cdot 4-38 \cdot 7\end{array}$ & $\begin{array}{l}10 \\
16 \cdot 6(2 \cdot 6) \\
7 \cdot 2-33 \cdot 2\end{array}$ & $\begin{array}{r}6 \\
19 \cdot 2(3 \cdot 7) \\
6 \cdot 1-28 \cdot 4\end{array}$ \\
\hline $\begin{array}{l}\text { GM-CSF }(\mathrm{pg} / \mathrm{ml}) \\
\text { No. of positive samples } \\
\text { value }\end{array}$ & $\begin{array}{c}1 \\
11 \cdot 3\end{array}$ & $\begin{array}{c}1 \\
15 \cdot 7\end{array}$ & $\underline{0}$ & $\begin{array}{c}1 \\
17 \cdot 8\end{array}$ \\
\hline $\begin{array}{l}\text { IFN- } \gamma(\mathrm{IU} / \mathrm{ml}) \\
\text { No. of positive samples } \\
\text { mean (SEM) } \\
\text { range }\end{array}$ & $\begin{array}{l}2 \\
23 \cdot 0(16 \cdot 5) \\
6 \cdot 5-39 \cdot 5\end{array}$ & $\frac{0}{-}$ & $\begin{array}{l}3 \\
25 \cdot 9(11 \cdot 5) \\
10 \cdot 0-54 \cdot 0\end{array}$ & $\begin{array}{r}4 \\
43 \cdot 8(32 \cdot 2) \\
4 \cdot 7-155 \cdot 3\end{array}$ \\
\hline $\begin{array}{l}\text { M-CSF (pg/ml) } \\
\text { No. of positive samples }{ }^{a}\end{array}$ & 0 & 0 & 0 & 0 \\
\hline
\end{tabular}

apsitive samples were those with measurable concentrations of cytokine in assays with the following sensitivities: $1.0 \mathrm{pg} / \mathrm{ml}$ (G-CSF and GM-CSF), $3.9 \mathrm{IU} / \mathrm{ml}$ (IFN- $\gamma$ ) and $15.2 \mathrm{pg} / \mathrm{ml}$ (MCSF).

${ }^{\circ}$ Mean (SEM) of positive samples.

SP, secondary polycythaemia; AP, apparent polycythaemia. (mean 6.8 minutes) than in normal subjects (mean 13.0 minutes). The patients with PPP in these assays had higher neutrophil counts (mean $7 \cdot 5 \times 10^{9} / 1$ ) than the normal subjects $\left(3.8 \times 10^{9} / 1\right)$ and, therefore, $E$ coli:neutrophil ratios were lower $(3 \cdot 2 v 9 \cdot 1)$. When data from all subjects were taken into account, the percentage of neutrophils undergoing phagocytosis correlated with the percentage of CD64 + neutrophils $(r=0.801, p<0.01)$. The phagocytic activity of monocytes from patients with PPP and monocytes and neutrophils from those with apparent polycythaemia were comparable with those from normal subjects.

\section{CYTOKINES}

G-CSF was detected in the serum samples of most subjects (table 3) and there was no significant difference in the frequency of G-CSF positive serum samples between patient groups and normal subjects ( $\chi^{2}$ test). The mean G-CSF concentration in each patient group was comparable with normal and there was no correlation between G-CSF concentration and receptor expression (percentage positive or MFC) for any of the markers tested. IFN- $\gamma$ was detected in nine of 43 samples and all patient values were within the range observed in normal subjects. GM-CSF could be measured in three serum samples (one PPP, one secondary polycythaemia, one normal) with similar values obtained in each. $\mathrm{M}$-CSF was not detected in any of the samples tested.

\section{Discussion}

The present study demonstrates that patients with PPP have increased percentages of circulating CD64 + neutrophils, CD64 + monocytes and CD14+ neutrophils. Monocytes from these patients also displayed increased expression of CD11b and CD64. These surface molecules were not upregulated on phagocytes from polycythaemic patients with polyclonal haemopoiesis (secondary and apparent polycythaemia). 
Increased expression of the high affinity receptor for IgG, CD64 (Fc $\gamma \mathrm{RI})$, is considered to be a marker of monocyte ${ }^{18}$ and neutrophil ${ }^{19}$ activation. In addition to promoting phagocytosis, ${ }^{2021}$ CD64 mediates cytotoxicity ${ }^{25}$ and activates the oxidative burst. ${ }^{19}$ IFN- $\gamma$ upregulates CD64 on monocytes ${ }^{18}$ and neutrophils $^{19}$ in vitro and on neutrophils in vivo ${ }^{26}$ whilst administration of G-CSF stimulates the de novo production of neutrophils expressing CD $64^{27}$ via its action on myeloid progenitor cells. ${ }^{28}$ Phagocytes from patients with streptococcal pharyngitis exhibit increased expression of $\mathrm{CD} 64,{ }^{29}$ which has been attributed to the endogenous production of IFN- $\gamma^{26}$ or $\mathrm{G}-\mathrm{CSF}^{27}$ in such infections. CD14, a receptor for LPS-LPS binding protein complexes, mediates phagocyte activation ${ }^{16}$ and enhances the adhesive activity of neutrophil CD11b. ${ }^{17}$ Expression of CD14 increases during differentiation of myelomonocytic cells ${ }^{16}$ and can be further upregulated on mature neutrophils by G-CSF and GM-CSF in vitro ${ }^{17}$ and by G-CSF in vivo. ${ }^{30}$ Thus, the increased percentages of CD64 + monocytes and neutrophils and of CD14 + neutrophils in patients with PPP suggests that these cells were activated in vivo. However, activation of monocytes and neutrophils by inflammatory stimuli results in the rapid upregulation of $\mathrm{CD} 11 \mathrm{~b} / \mathrm{CD} 18,{ }^{15}$ but in the present study the expression of this molecule by PPP neutrophils was comparable with that in normal subjects. That CD14 and CD64, but not CD11b, were upregulated on PPP neutrophils may be explained by the augmented expression of surface adhesion molecules being dependent upon the nature of the stimulus and the local environment. For example, the response of neutrophils to activating factors in the bone marrow could be distinct from those operating in the circulation or at sites of inflammation/infection. Moreover, this responsiveness may also be dependent upon the cell type, as illustrated by the finding of enhanced CD11b on PPP monocytes in our study.

In the present study the concentrations of G-CSF, GM-CSF and IFN- $\gamma$ in the serum samples of patients with PPP were not increased and there was no correlation between concentrations of these cytokines and the expression of surface receptors on phagocytes. Although patients with PPP have been previously reported to have increased serum immunoreactive $\mathrm{M}-\mathrm{CSF}^{31}$ we were unable to detect biologically active M-CSF in any of our samples despite using a sensitive cell proliferation bioassay. The lack of concordance between receptor expression on circulating phagocytes and cytokine concentrations in serum may reflect the paracrine nature of the haemopoietic microenvironment. Measurements of cytokines in serum may not reflect their concentrations in the bone marrow as cytokines, such as the CSFs produced in the bone marrow stroma, are immobilised by the local extracellular matrix. ${ }^{32}$ Alternatively, the abnormal phenotype of PPP phagocytes may be an inherent characteristic transmitted by the neoplastic stem cell rather than the result of cytokine mediated activation. Such a model has been previously proposed to account for increased expression of $\mathrm{Fc}$ receptors by neutrophils $^{33}$ and platelets ${ }^{34}$ in PPP and could involve maturation defects within the abnormal clone. For example, CD64 is expressed by normal granulocyte precursors up to the metamyelocyte but is lost during terminal differentiation. ${ }^{28}$ However, the present finding of increased phagocytic activity of PPP neutrophils, despite a lower $E$ coli:neutrophil ratio than for normal subjects in the assay system used, together with abnormally high percentages of CD14 + and CD64 + neutrophils, suggests activation rather than persistence of an immature phenotype.

The clinical complications of PPP, which include manifestations of increased blood viscosity, thrombosis and haemorrhage, are largely attributed to elevated red cell mass and abnormal platelet function. ${ }^{2}$ However, the ability of activated normal neutrophils to stimulate platelet aggregation ${ }^{35}$ and the expression of procoagulant activity by activated normal macrophages, ${ }^{36}$ suggests that monocytes and neutrophils could contribute to the pathogenesis of thrombotic complications in PPP.

1 Adamson JW, Fialkow PJ, Murphy S, Prchal JF, Steinmann L. Polycythemia vera: stem-cell and probable clonal origin of the disease. N Engl F Med 1976;295:913-16.

2 Lewis SM, Pearson TC. Non-leukaemic myeloproliferative disorders. In: Hoffbrand AV, Lewis SM, eds: Postgraduate haematology. 3rd edn. Oxford: Heinemann, 1989:530-59.

Blanchard KL, Gilliland DG, Bunn HF. Clonality in myeloproliferative disorders. Am F Med Sci 1992;304:125-30.

4 Goldman JM. Granulocytes, monocytes, and their benign disorders. In: Hoffbrand AV, Lewis SM, eds: Postgraduate haematology. 3rd edn. Oxford: Heinemann, 1989:294-324.

5 Wagner R. Studies on the physiology of the white blood cell. The glycogen content of leukocytes in leukemia and polycythemia. Blood 1947;2:235-43.

6 Mitus WJ, Bergna LJ, Mednicoff IB, Dameshek W. Alkaline phosphatase of mature neutrophils in chronic forms of the myeloproliferative syndrome. Am f Clin Pathol 1958; 30:285-94.

7 Luganova IS, Seitz IE. Glycogen content and normal metabolism in normal and leukemic human leukocytes. Fed Proc Trans Suppl 1963;22:1058-61.

8 Cooper MR, DeChatelet LR, McCall CE, Spurr CL. The activated phagocyte of polycythemia vera. Blood 1972;40: 366-74.

9 Corberand J, LaHarrague P, DeLarrard B, Nguyen F, Pris $\mathrm{J}$. Phagocytosis in myeloproliferative disorders. Am $\mathcal{f}$ Clin Pathol 1980;74:301-5.

10 McCall CE, Caves J, Cooper R, DeChatelet L. Functional characteristics of human toxic neutrophils. F Infect Dis 1971;124:68-75.

11 Ghosh ML, Hudson G, Blackburn EK. Skin window studies in polycythaemia rubra vera. $B r \mathcal{F}$ Haematol 1975;29: 461-7.

12 Hopen G. Granulocyte and platelet adhesiveness in malignant paraproteinaemia, leukaemia and myeloproliferative diseases. Scand F Haematol 1981;27:339-45.

13 Gilbert HS, Ward L. Augmented granulocyte adherence: an intrinsic abnormality in polycythemia vera [abstract] Blood 1976;48:971a.

14 Brandt L. Phagocytic activity of neutrophilic leukocytes in polycythemia vera. Scand F Haematol 1967; Suppl 2: 54-64.

15 Arnaout MA. Structure and function of the leukocyte adhesion molecules CD11/CD18. Blood 1990;75:1037-50.

16 Ziegler-Heitbrock HWL, Ulevitch RJ. CD14: cell surface receptor and differentiation marker. Immunol Today 1993; 14:121-5.

17 Wright SD, Ramos RA, Hermanowski-Vosatka A, Rockwell P, Detmers PA. Activation of the adhesive capacity of CR3 on neutrophils by endotoxin: dependence on lipopolysaccharide binding protein and CD14. F Exp Med 1991;173:1281-6.

18 Jayaram Y, Buckle AM, Hogg N. The Fc receptor, FcRI, and other activation molecules on human mononuclear phagocytes after treatment with interferon-gamma. Clin Exp Immunol 1989;75:414-20.

19 Akerley WL, Guyre PM, Davis BH. Neutrophil activation through high-affinity Fc gamma receptor using a monomeric antibody with unique properties. Blood 1991;77: meric antib.

20 Ruiz P, Gomez F, Lopez R, Chien P, Rossman MD, Schreiber A. Granulocyte Fc gamma receptor recognition 
of cell bound and aggregated IgG: effect of gammainterferon. Am $\mathcal{F}$ Haematol 1992;39:257-63.

21 Anderson CL, Shen L, Eicher DM, Wewers MD, Gill JK. Phagocytosis mediated by three distinct Fc gamma receptor classes on human leukocytes. 7 Exp Med 1990; 171:1333-45.

22 Berlin NI. Diagnosis and classification of the polycythemias. Semin Haematol 1975;12:339-51.

23 Wadhwa M, Bird C, Tinker A, Mire-Sluis AR, Thorpe R. Quantitative biological assays for individual cytokines. In: Balkwill FR, ed. Cytokines. A practical approach. Oxford: IRL Press, 1991:309-30

24 Meager A. RIA, IRMA and ELISA assays for cytokines. In: Balkwill FR, ed. Cytokines. A practical approach. Oxford: IRL Press, 1991:299-307.

25 Shen L, Guyre PM, Fanger MW. Polymorphonuclear leukocyte function triggered through the high affinity $\mathrm{FC}$ receptor for monomeric IgG. F Immunol 1987;139:534-8.

26 Huizinga TWJ, van der Schoot CE, Roos D. Induction of neutrophil Fc-gamma receptor I expression can be used as a marker for biologic activity of recombinant interferongamma in vivo. Blood 1991;77:2088-90.

27 Repp R, Valerius T, Sendler A, Gramatzki M, Iro H, Kalden JR R, Vl. IgG (Fc gamma RI, CD64) after in vivo application of recombinant human granulocyte colony-stimulating facrecombinant human gran

28 Kerst JM, van de Winkel JGJ, Evans $\mathrm{AH}$, de Haas M, Slaper-Cortenbach IC, de Wit TP, et al. Granulocyte colony-stimulating factor induces $\mathrm{hFc}$ gamma RI (CD64 antigen)-positive neutrophils via an effect on myeloid precursor cells. Blood 1993;81:1457-64.

29 Guyre PM, Campbell AS, Kniffin WD, Fanger MW. Monocytes and polymorphonuclear neutrophils of patients with streptococcal pharyngitis express increased numbers of type I IgG Fc receptors. F Clin Invest 1990;86:1892-6.

30 Hansen PB, Kjaersgaard E, Johnsen HE, Gram J, Pedersen $M$, Nikolajsen K, et al. Different membrane expression of CD11b and CD14 on blood neutrophils following in vive administration of myeloid growth factors. $\mathrm{Br} 7 \mathrm{Haematol}$ 1993;85:50-6.

31 Gilbert HS, Praloran V, Stanley ER. Increased circulating CSF-1 (M-CSF) in myeloproliferative disease: association CSF-1 (M-CSF) in myeloproliferative disease: association with myeloid metaplasia and perip

32 Campbell AD, Wicha MS. Extracellular matrix and the hematopoietic microenvironment. F Lab Clin Med 1988; 112:140-6.

33 Gilbert HS, Goldberg R, Ward L. Increased circulating neutrophils with surface receptor activity for immunoglobulin $\mathrm{G}$ in polycythemia vera and myeloid metaplasia. Blood 1979;53:1106-13.

34 Moore A, Nachman RL Platelet Fc receptor Increased expression in myeloproliferative disease. $\mathcal{F}$ Clin Invest 1981; 67:1064-71.

35 Faint RW. Platelet-neutrophil interactions: their significance. Blood Rev 1992;6:83-91.

36 Schwager I, Jungi TW. Effect of human recombinant cytokines on the induction of macrophage procoagulant activity. Blood 1994;83:152-60. 